\title{
Processing Subject-Object Ambiguities in the L2: A Self-Paced Reading Study With German L2 Learners of Dutch
}

\author{
Else Havik \\ Radboud University Nijmegen
}

\section{Leah Roberts}

Max Planck Institute for Psycholinguistics

\section{Roeland van Hout}

Radboud University Nijmegen

\section{Robert Schreuder}

Radboud University

Max Planck Institute for Psycholinguistics

\section{Marco Haverkort*}

Radboud University Nijmegen

The results of two self-paced reading experiments are reported, which investigated the online processing of subject-object ambiguities in Dutch relative clause constructions like Dat is de vrouw die de meisjes heeft/hebben gezien by German advanced second language (L2) learners of Dutch. Native speakers of both Dutch and German have been shown to have a preference for a subject versus an object reading of such temporarily ambiguous sentences, and so we provided an ideal opportunity for the transfer of first language (L1) processing preferences to take place. We also investigated whether the participants' working memory span would affect their processing of the experimental items. The results suggest that processing decisions may be affected by working memory when task demands are high, and in this case the high working memory span learners patterned like the native speakers of lower working memory. However, when reading

* Marco Haverkort died on May 3, 2006.

Correspondence concerning this article should be addressed to Leah Roberts, Max Planck Institute for Psycholinguistics, PO Box 310, 6500 AH Nijmegen, The Netherlands. Internet: Leah.Roberts@mpi.nl 
for comprehension alone and when only structural information was available to guide parsing decisions, working memory span had no effect on the L2 learners' online processing, and this differed from the native speakers' online processing even though the L1 and the L2 are highly comparable.

Keywords L2 processing; reading comprehension; working memory; ambiguity

\section{Introduction}

Although there is a considerable body of research on monolingual real-time sentence comprehension, sentence processing in the second language (L2) has only recently become a topic of interest. Much work in this developing field is devoted to the question of how nativelike L2 sentence processing might be, and if not, how and to what extent the first language (L1) might influence the processing of the L2. A review of the literature suggests that whether the L1 plays a role in L2 online processing may depend on the linguistic level being examined. Specifically, it appears that when L2 learners have to make online processing decisions based on lexical-semantic and/or thematic information, they process the input like native speakers of the target language (e.g., Felser \& Roberts, 2004; Felser, Roberts, Gross, \& Marinis, 2003; Papadopoulou \& Clahsen, 2003; Williams, 2006; Williams, Möbius, \& Kim, 2001). Where the $\mathrm{L} 1$ and the L2 differ in this regard, for instance, with differences between verb subcategorization properties between the two languages, a fleeting influence of the L1 may be in evidence (Altarriba, Kroll, Sholl, \& Rayner, 1996; FrenckMestre \& Pynte, 1997). However, the investigation of L2 learners' syntactic processing has found divergent results with regard to nativelikeness. Findings from some studies suggest that L2 learners' processing is essentially targetlike, irrespective of the properties of the L1. This appears to be the case particularly in those studies in which the participants are required to undertake some metalinguistic task as well as general reading comprehension (e.g., Juffs \& Harrington, 1995, 1996; Williams et al.). The results of others (which have required participants to read for meaning alone) have found that L2 processing might be fundamentally different from L1 processing, even when the learners perform like native speakers in offline comprehension tasks and even when the constructions under investigation are similar between the L1 and the target language (Felser \& Roberts, 2007; Marinis, Roberts, Felser, \& Clahsen, 2005; Papadopoulou \& Clahsen). In order to account for this latter finding, it has been suggested that L2 learners are not as able as native speakers to make use of syntactic information in online L2 comprehension and that they might compensate 
with an overreliance in their use of lexical-semantic, thematic, and pragmatic information in order to come to the correct interpretation of a sentence. Some go so far as to suggest that even though L2 learners can successfully interpret a sentence, the representations that are created during online processing lack complex hierarchical structure and abstract syntactic elements like movement traces (Clahsen \& Felser, 2006a, 2006b). If this is the case, the prediction is that even when a construction is highly comparable between the L1 and the L2, if online processing decisions must be made on the basis of syntactic information alone, then L2 learners might perform differently than native speakers. In the current study we examine this question by asking whether L2 learners of Dutch with a typologically and lexical-semantically highly related L1, German, process relative clauses that are temporarily ambiguous between a subject and object reading like native speakers of Dutch, when disambiguation is achieved via morphosyntactic means alone (number agreement). Given that such constructions in Dutch and German are highly comparable and that monolingual speakers of both show the same preference for subject versus object readings in such sentences, we are able to test whether the L2 learners transfer their L1 structurally based processing preference to the L2 input.

In the current study we are also concerned with the potential influence of available working memory (WM) capacity (in either the L1 or the L2) on L2 sentence processing. WM capacity is traditionally measured by a so-called Reading Span Test (Daneman \& Carpenter, 1980). In monolingual research, performance on (a version of) this test has been found to be related to different online and offline measures of language comprehension, as well as to the processing of ambiguous sentences (Friederici, Steinhauer, Mecklinger, \& Meyer, 1998; Just \& Carpenter, 1992; King \& Just, 1991; Vos, 1999). With regard to L2 comprehension, positive correlations have been reported between reading span scores and performance on offline measures of L2 comprehension (e.g., Harrington \& Sawyer, 1992) and grammaticality judgment tasks (Robinson, 2002). However, with regard to how well WM differences might explain within-group variation in online L2 processing, little systematic research has been done, and, in general, no effects have been found. For instance, in a recent study on antecedent priming (Felser \& Roberts, 2007), the memory span scores of the group of Greek L2 learners of English that were tested did not affect their processing of the experimental items, even though this was the case for the native adult and child groups to which the learners were compared. However, the L2 learners in the Felser and Roberts study undertook the WM test in their L2 only, and as the authors themselves stated, the group was rather homogenous, 
with all but one participant falling into the "high span" range. This means that the group could not be usefully divided to specifically investigate WM effects. It may be that such a test undertaken in the L2 alone does not offer the scope to pick up potential variations in WM span. Juffs $(2004,2005)$ investigated the relationship between online comprehension and WM span in both the L1 and the L2 of Chinese, Japanese, and Spanish learners of English. He investigated potential correlations between the L2 learners' WM scores and their mean reading times on the critical (disambiguating) verb "looked" in temporarily ambiguous sentences like After the children cleaned the house looked very neat and tidy. Analyses were also performed to investigate the groups' moment-by-moment processing, where they were divided according to their median WM score to see whether high and low WM groups read the experimental items differently. No significant effects of WM were found in either analysis; that is, individual variations in the reading times on the critical region in the experimental sentences were not significantly related to the participants' WM scores. However, as the author himself noted, the groups were not matched for proficiency in English, in particular the Japanese L2 learners who were both much less proficient and much slower at reading than the other L2 groups. Despite this potential proficiency confound, the data were collapsed across language groups for the two WM analyses and, therefore, it is possible that such proficiency differences among the L2 learner groups may have masked any potential effects of WM on the online processing of the experimental items.

It would seem, then, that in order to obtain a clearer picture of potential memory span effects on L2 processing, a test in both the L1 and the L2 should be undertaken and, furthermore, the L2 learners should be as highly matched as possible on other variables that may potentially influence online processing times. As in the work of Juffs $(2004,2005)$, in the current study we, too, investigate potential WM span effects on the real-time processing of the experimental sentences. However, rather than investigating correlations with processing difficulty (i.e., the experimental manipulation itself) we investigate whether differences in memory span affect the participants' processing of the disambiguating region. We also attempt to avoid the potentially confounding factor of language background by testing one group of L2 learners who are closely matched for proficiency in the L2 and educational experience.

Before we present the results of the current study, we first summarize findings on the processing of subject-object ambiguities by German and Dutch native speakers and then briefly give an overview of the findings of research into L2 processing of temporary ambiguities. 


\section{Processing Subject-Object Ambiguities in Dutch and German}

The current study investigates the processing of temporarily ambiguous sentences with subject (1) or object (2) relative clauses by German L2 learners of Dutch, in comparison to a group of Dutch native speakers.

(1) Dat is de vrouw die de meisjes heeft gezien. [subject relative]

That is the woman who the girls has seen.

[That is the woman who has seen the girls.]

(2) Dat is de vrouw die de meisjes hebben gezien. [object relative]

That is the woman who the girls have seen.

[That is the woman whom the girls have seen.]

In the above two relative clause constructions, the NPs de vrouw and de meisjes are not marked for (nominative/accusative) case and so are ambiguous until number agreement on the auxiliary heeft/hebben determines their syntactic function.

In German, relative clauses are almost identical to these Dutch examples, except that the relative pronoun and the NP can be overtly marked for nominative or accusative case. The feminine relative pronoun, die, however, can be used for both nominative and accusative forms in the singular and plural, and, therefore, in similar German sentences with feminine nouns, as in (3), case marking cannot be used to disambiguate between subject and object relative sentences, and the resulting construction is highly comparable to the Dutch examples (1) and (2).

(3) Das ist die Frau die die Mädchen gesehen hat/haben.

That is the woman who the girls seen has/have.

[That is the woman who has seen the girls/whom the girls have seen.]

The online processing of this type of subject-object ambiguity in both Dutch and German has been extensively investigated, and monolingual speakers of both languages display the same subject-over-object preference in such constructions. For instance, the results from studies employing reading-time, eyetracking, and event-related potential (ERP) methodologies have shown that native speakers of both Dutch and German find processing more difficult when such temporarily ambiguous constructions are disambiguated toward an object-relative clause in comparison to a subject-relative clause, and in wholly ambiguous constructions, readers demonstrate a strong preference for a subject-relative interpretation versus an object-relative interpretation (Frazier, 1987; Frazier \& Flores d'Arcais, 1989; Gorrell, 2000; Kaan, 1997; Konieczny, 
Hemforth, Scheepers, \& Straube, 1997; Schriefers, Friederici, \& Kuhn, 1995). This appears to be the case even in the face of conflicting plausibility or contextual information (Mecklinger, Schriefers, Steinhauer, \& Friederici, 1995; van Gompel, 1995).

Structurally based parsing theories appeal to processing economy principles to account for this observed subject-first preference, although they differ in their precise details (e.g., The Active Filler Strategy, Clifton \& Frazier, 1989; The Phrase-Structure Approach, Gorrell, 1995; The Minimal Chain Principle, De Vincenzi, 1991). The Active Filler Strategy (Clifton \& Frazier) states that the preference for the subject analysis in the processing of Dutch and German relative clauses is observed because the parser will always attempt to relate a $w h$-item - here the relative pronoun die - to the first available gap position, thus the parser will prefer to postulate a subject gap, as in (4a). Processing is more costly in the object relative construction (4b), because when the disambiguating material is encountered at the verb, it is clear that this preferred analysis was incorrect, and revision must take place.

(4a) de vrouw die $t_{\mathrm{i}}$ de meisjes heeft gezien. [SO]

(4b) de vrouw die $\mathrm{i}_{\mathrm{i}}$ de meisjes $t_{\mathrm{i}}$ hebben gezien. [OS]

All phrase-structure approaches assume that the parsing procedures underlying the observed subject-first preference in languages like Dutch and German are purely syntactically driven operations and that processing difficulty arises because the syntactic commitments the parser makes prior to encountering the disambiguating verb have to be revised. Therefore, investigating the processing of this type of construction by German L2 learners of Dutch allows for a direct test of whether syntactic processing procedures are comparable in L1 and L2 processing.

\section{Processing Subject-Object Ambiguities in the L2}

Although much L2 sentence processing research has focused on the processing of ambiguities, most studies have looked at the processing of L2 learners of English; for example, Juffs and Harrington (1995) found that L2 learners slowed down when reading the main verb proved in $(5 \mathrm{a})$ in constructions with optionally transitive verbs like drank in comparison to the same position in sentences where the initial verb was obligatorily intransitive (5b). This measurable processing difficulty suggests that in $(5 \mathrm{a})$, the readers, both native and nonnative, initially interpreted the ambiguous NP the water as the direct object of the preceding verb drank, they were "led up the garden-path"; with the 
reanalysis of this NP as subject of the main verb causing the observed processing cost.

(5a) After Bill drank the water proved to be poisoned.

(5b) After Sam arrived the guests began to eat and drink.

Thus, like native speakers, L2 learners incrementally process the input in real time, and they attempt to link arguments with their potential subcategorizers as soon as possible. Other studies have found more evidence for this and have furthermore found that the strength of the processing difficulty in the processing of such subject-object ambiguities in English differs as a function of the plausibility of the initial interpretation (Felser \& Roberts, 2004; Williams, 2006; Williams et al., 2001); for example, using a word-by-word plausibility judgment task, Williams showed that both L2 learners and native speakers found the disambiguating NP more difficult to process following disambiguation if it was a plausible direct object (fix - machine) as in (6a) in comparison to when it led to an implausible sentence fragment (fix - customer) (see also Williams et al.).

(6a) Which machine did the mechanic fix the motorbike with two weeks ago?

(6b) Which customer did the mechanic fix the motorbike for two weeks ago?

Measures of processing difficulty in English studies like this are confined to the processing of a temporarily ambiguous NP that has followed the presentation/processing of a (potentially) subcategorizing verb. Therefore, it is the meaning of this verb that dictates whether the following NP is (erroneously or not) taken to be one of its arguments. Beacuse it seems clear that L2 learners are able to use online such semantic-thematic information in analyzing the syntactic roles of NPs, the question arises as to whether this is the case in the presence of syntactic information alone for obligatory arguments. Investigating subject-object relative clause ambiguities in Dutch with morphosyntactic disambiguation via subject-verb agreement allows us to address this question, because both NPs are encountered before the verb.

One recent L2 processing study has looked at the online comprehension of subject-object ambiguities in German and is thus more informative in relation to the current study than those looking at the phenomenon in English. Hopp (2006) used word-by-word self-paced reading followed by a truth value judgment task to test English and Dutch L2 learners of German. Included in the experimental 
items were scrambled sentences for which disambiguation toward either a subject (7a) or an object ( $7 b)$ reading was achieved via number information on the sentence-final auxiliary verb.

(7a) Sie sagt, dass die Baronin am Freitag die Bankiers eingeladen hat. She says that the baroness on Friday the bankers invited has.

(7b) Sie sagt, dass die Baronin am Freitag die Bankiers eingeladen haben. She says that the baroness on Friday the bankers invited have.

All groups showed elevated reading times on the sentence-final auxiliary verb when it was disambiguated toward the (dispreferred) object-subject reading (7b) in comparison to the subject-object items (7a). This suggests that like native speakers of German, the L2 learners had a preference for a subjectfirst reading, even the English learners with no comparable structures in their L1. However, it is not clear that the participants had in fact understood these object-subject experimental items, as even the German native speakers were accurate in the verification task only $28 \%$ of the time (advanced English $=23 \%$; advanced Dutch $=28 \%$ ). The near-native groups were more accurate, but they still achieved very low scores (near-native English $=44 \%$; near-native Dutch $=45 \%$ ). Thus, the reading-time data analyses necessarily had to be performed on data for items that the participants may well have not correctly understood. In sum, although the L2 learners, like the native speakers, showed a clear preference for subject-first word order as shown by their very high accuracy in the subject-object conditions, conclusions with regard to the process of reanalysis of the object-subject items are difficult to draw, because it seems that the majority of these items ultimately caused processing breakdown, even for native speakers of the language. So if reanalysis did indeed take place, it appears to have been unsuccessful most of the time. What may be more informative as to the process of reanalysis would be to examine reading times (RTs) on the disambiguating verb for items for which the initially erroneous parse is successfully detected and corrected. The difficulty that the readers had with the (object-resolved) experimental items in the Hopp study may have been caused by the fact that the constructions that were used were scrambled sentences, with little discourse-pragmatic-related reason for object-over-subject scrambling. ${ }^{1}$ In the current study, we use more everyday constructions so that should the dispreferred analysis be encountered, it would be less likely to lead to processing breakdown. Additionally, because the reader encounters the relative pronoun early in our current study, they are perhaps more open to an object-relative analysis and thus may be more likely to treat the object-resolved 
items as dispreferred rather than possibly unlicensed (Bader \& Meng, 1999; Bornkessel \& Schlesewsky, 2006).

\section{The Current Study}

The aim of the current study is twofold. We investigate whether German L2 learners of Dutch process subject-object ambiguities in relative clauses like native Dutch speakers, and we ask whether there is an effect of working memory span in the processing of these constructions for either group.

\section{Experiment 1}

\section{Method}

Participants

Twenty-four native speakers of German (19 females; mean age $=20.8 ; S D=$ 1.8) participated in the experiment. All participants had recently undergone an intensive Dutch course ( $8 \mathrm{hr}$ a day for 4.5 weeks) specifically aimed at German students at the Radboud University in Nijmegen. Although this appears to be a short time, after the course, all participants passed the Dutch exam for L2 Learners of Dutch (Interuniversitair Toelatingsexamen Nederlands [ITN]), indicating that they were proficient enough in Dutch to enroll and fully participate as a student at any university in the Netherlands. None reported having been exposed to Dutch before starting the intensive course. A control group of 24 native speakers of Dutch (university students, 17 females, mean age $=20.6$; $S D=2.0$ ) also participated. All participants had normal or corrected to normal vision and were paid a small fee for their participation.

\section{Materials}

Sixty-four sentence quadruplets comprising ambiguous relative clause constructions were created. After an introductory phrase (that is or there goes), a relative clause followed, consisting of a relative pronoun (die) and then a singular NP followed by a second plural NP. The constructions were temporarily ambiguous between a subject relative (SR) and an object relative (OR) reading up until the auxiliary (heeft/hebben), where disambiguation was achieved via number agreement between the auxiliary verb and one of the two preceding NPs: a past participle followed the auxiliary verb. ${ }^{2}$ We also manipulated the length of the sentence types. In the short experimental items, the disambiguating auxiliary was presented immediately following the second NP, and in the 
long versions, a padding phrase was added between the second NP and the disambiguating auxiliary verb, which comprised a prepositional phrase of six words; therefore, syntactic ambiguity was prolonged in the long versions of the items. Lengthening the ambiguous region has been found to magnify processing effects. Specifically, monolingual research has shown that the longer a reader is committed to an erroneous analysis (as would be the case in the long OR sentences), the more costly the reanalysis process (e.g., Pickering \& Traxler, 1998), and we wished to see whether this would also be the case for L2 learners. The manipulation of these two factors, Sentence Type (SR vs. OR) and Sentence Length (short vs. long), thus led to four different experimental conditions:

\section{(8a) Subject Relative-Short}

Daar is de machinist die de conducteurs heeft bevrijd uit het brandende treinstel.

That is the engine-driver who the guards has saved from the burning traincarriage.

(8b) Object Relative-Short

Daar is de machinist die de conducteurs hebben bevrijd uit het brandende treinstel.

That is the engine-driver who the guards have saved from the burning traincarriage.

(8c) Subject Relative-Long

Daar is de machinist die de conducteurs na het ongeluk met de trein heeft bevrijd uit het brandende treinstel.

That is the engine-driver who the guards after the accident with the train has saved from the burning train-carriage.

(8d) Object Relative-Long

Daar is de machinist die de conducteurs na het ongeluk met de trein hebben bevrijd uit het brandende treinstel.

That is the engine-driver who the guards after the accident with the train have saved from the burning train-carriage.

Only NPs with common gender were used because relative pronouns that accompany neuter NPs are overtly marked for gender and would thus immediately disambiguate the sentence. Both NPs were animate, and they were chosen in such a way that both were equally likely to be either the agent or the patient of the action expressed by the verb cluster. We wished to examine purely syntactic processing decisions, and so to avoid any semantic bias 
toward one interpretation, the symmetry of all "noun-verb-noun" combinations was established with a plausibility rating by 32 university students. The two possible sentences that could be formed with each combination (e.g., de machinist bevrijdde de conducteurs or de conducteurs bevrijdden de machinist) were assigned to two different lists. Seventy more or less implausible sentences were included as filler sentences. The plausibility of the clauses were rated on a scale from 1 (very implausible) to 7 (very plausible). All 64 noun-verbnoun combinations that were used in this study were rated 5 or higher on the plausibility scale. The difference between the ratings on both versions did not exceed 1 .

We attempted to ensure that the German L2 learners would be familiar with the vocabulary used in the experimental materials by selecting the nouns and verbs from either the vocabulary list used in the L2 Dutch course or from the basic word dictionary Basiswoordenboek Nederlands (de Kleijn \& Nieuwborg, 2001).

All sentences in the self-paced reading task were followed by a verification statement to check whether the meaning of the sentence was understood correctly. The verification statements concerned the subject/object interpretation of the NPs in the preceding sentence and were formulated as active sentences in the past tense that were to be judged, half of them as true and the other half as false. Half of the statements were structured as NP1 verb-ed NP2 (e.g., de machinist bevrijdde de conducteurs) and the other half as NP2 verb-ed NP1 (de conducteurs bevrijdden de machinist). A set of 16 distractor sentences were also included in the stimuli lists.

The 64 experimental items were evenly distributed across experimental lists such that each participant saw every experimental sentence, but never saw more than one version of each. Including the 16 filler sentences, each participant read a total of 80 items, presented in four experimental blocks of 20 items, randomized separately per block and per participant.

For the analysis of the reading times in the self-paced reading task, we focused on the reading time data on four words in the disambiguating region, the disambiguating auxiliary, the past participle, the preposition/conjunction, and the determiner (labeled positions 0 to 3 ).

\section{Procedure}

Participants were seated in front of a PC screen. They were instructed to read the sentences silently, at their own pace. Each sentence was presented word by word, using the moving-window technique (Just, Carpenter, \& Woolley, 1982). At the beginning of each sentence, a fixation point indicated where 
the sentence would start. Using a push-button box, the participant pressed the middle button to bring up the first word of the sentence, which appeared in the center of the screen. All other words in the sentence were represented by dashes. After pressing this button again, the second word became visible and the first word was replaced by a dash, continuing until the end of the sentence. In this manner, reading times were recorded for every word in the sentence. When the participant pressed the middle button after the last word of the sentence, the word bewering "statement" appeared in the middle of the screen, followed by the verification statement, which appeared in full. The participant read this sentence and was required to judge whether the content of the statement was consistent with the preceding sentence, pressing the right button when it was consistent and the left button when it was inconsistent (the words true and false were written above the right and left button, respectively). The experiment began with 10 practice sentences, the data from which were not analyzed.

To assess the participants' WM span, both the native Dutch and the L2 groups undertook a memory span test that was measured by a Dutch version of the Daneman and Carpenter Reading Span Test (Daneman \& Carpenter, 1980). The L2 group also undertook a reading span test in German. Both tests were adapted from the original English version, with improved methodological criteria (see Van den Noort, Bosch, \& Hugdahl, 2006). In the tests, a total number of 100 sentences was presented on a computer screen in sets varying in size from 2 to 6 sentences, 1 sentence at a time. Participants were instructed to read at a regular pace while paying attention to the content of the sentences. As soon as they had finished reading the last word of a sentence, the experimenter pressed a button and the sentence disappeared. At the end of a set, a cue (RECALL) appeared, and the participant had to recall all of the sentence-final words of the previous set. These words did not need to be recalled in the original order, and there was no time limit on recalling. WM capacity was indicated by the total number of sentence-final words a participant was able to recall throughout the whole test (maximum $=100$ words). Total administration time varied from $20 \mathrm{~min}$ (for the native speakers) to $30 \mathrm{~min}$ (for the L2 speakers). The mean WM span score for the Dutch natives was $81(S D=8)$. The L2 learners scored significantly higher in their L1 German (mean $=83, S D=9)$ than in their L2 Dutch working memory span tests (mean $=73, S D=11), t(23)=$ $6.99, p<.001$. In comparison to the native speakers, the L2 learners had a significantly lower Dutch WM span score, $t(46)=2.75, p<.01$, but there was no difference between the scores for the two groups when performing the task in their respective native languages, $t(46)=0.663, p>.4$. 
Table 1 Proficiency scores German L2 learners

\begin{tabular}{llccccr}
\hline & & Reading & Writing & Listening & Speaking & Total \\
\hline L2 learners & Mean & 84.2 & 78.1 & 92.2 & 74.8 & 82.3 \\
& $S D$ & 6.9 & 11.6 & 6.9 & 8.9 & 6.2 \\
\hline
\end{tabular}

Note. Maximum score for each part is 100 . To pass the exam, one needs at least a score of 60 .

Table 2 Mean reading times $(S D s)$ collapsed across the four critical segments and mean accuracy scores (\%) to the verification statements that followed each experimental sentence in Experiment 1

\begin{tabular}{llcccc}
\hline & & SR_short & OR_short & SR_long & OR_long \\
\hline Native speakers & RT & $503(108)$ & $539(108)$ & $513(140)$ & $568(150)$ \\
& Accuracy & $95(6)$ & $83(21)$ & $92(7)$ & $82(23)$ \\
L2 learners & RT & $767(130)$ & $757(174)$ & $764(184)$ & $788(175)$ \\
& Accuracy & $86(15)$ & $80(13)$ & $81(14)$ & $73(19)$ \\
\hline
\end{tabular}

Note. $\mathrm{SR}=$ subject-relative clause, $\mathrm{OR}=$ object-relative clause.

All participants in the L2 group started the 2-h test session with a reading span test (half the Dutch and half the German test first). Then the participants filled in a language background questionnaire. Following this, the self-paced reading test was administered, with a short break halfway through the session. The same tests were administered to the L1 group, except for the German reading span test and the language background questionnaire. Table 1 shows the scores across for the proficiency measures.

\section{Results}

Before any analyses, the RT data were screened for outliers. All RTs longer than 3,000 $\mathrm{ms}$ for the L1 group and longer than 4,000 $\mathrm{ms}$ for the L2 group as well as those shorter than $125 \mathrm{~ms}$ were excluded, affecting $0.44 \%$ of the L 1 and $0.55 \%$ of the L 2 data. Additionally, RTs were analyzed for only those items for which there was an accurate response to the verification statement that followed. Table 2 shows the mean RTs collapsed across the four critical segments in the critical region and the mean accuracy scores on the verification statements for the two groups. As can be seen, for both groups the OR_long items were read more slowly overall than the other three conditions, and, furthermore, responses to the verification statements following these items were the least 
accurate and those to the SR_short items were the most accurate. Below we perform two separate analyses. First, we ran an ANOVA per group on their mean RTs collapsed across the four critical segments with the within-subjects factors Sentence length (long/short) and Sentence type (object relative/subject relative) and the participants' WM span score as a covariate factor. The purpose of this preliminary analysis is to see whether the processing of the experimental items in general is affected by the participants' WM span. If so, and the covariate factor WM span interacts with either of the within-subjects factors Sentence type and Sentence length, the groups are then split according to the median span score for their group into a high-memory span and a low-memory span group for the second part of the analysis. In this second analysis, we investigate the specific effects of the experimental variables on the word-by-word processing of the sentences and any differences between the groups, by performing separate between-groups ANOVAs on each of the critical segments of the experimental sentences.

To investigate whether WM span affected either of the group's overall processing of the experimental sentences, preliminary ANOVAs per group were run on these collapsed mean RTs with the within-subjects factors Sentence type (object relative/subject relative) and Sentence length (long/short) and with WM span score as a covariate factor. There was a marginal effect of WM for the native speakers (Length $\times$ Type $\times$ WM: $F(1,22)=3.51, p=.074$, partial $\left.\mathrm{\eta}^{2}=.14\right)$, and for the L2 learners, RTs on the experimental sentences were affected both by their Dutch (Length $\times$ Type $\times$ WM: $F(1,22)=7.02, p=$ .015 , partial $\eta^{2}=.24$ ) and their German WM span scores (Length $\times$ Type $\times$ WM: $F(1,22)=5.44, p=.029$, partial $\left.\eta^{2}=.20\right)$. The fact that the covariate factor WM span score interacted with other experimental variables allowed us to split the groups according to their WM span scores in order to investigate their word-by-word processing of the experimental items. For the purposes of between-groups analyses on the word-by-word RTs, we therefore divided the native speakers into two groups based on their median WM score (81), leading to a group of 12 high-WM span and 12 low-WM span native speakers. Because the learners' RTs were affected by their WM in both languages and because these two were highly correlated ( $r=.81, n=24, p<.001)$, we divided the L2s into a high-WM span group who scored above the median on the memory tests in both their L1 (83.5) and their L2 (75) $(n=10)$ and a low-span group who scored below the median on both tests $(n=9){ }^{3}$ Table 3 shows the mean WM span score for both groups ${ }^{4}$ and the mean RTs on each of the critical segments for the native speakers and the two L2 learner groups. The results of a one-way between-groups ANOVA found that there was a statistically 
Table 3 Mean WM span scores $(\mathrm{D}=$ Dutch, $\mathrm{G}=$ German $)$ and mean reading times $(S D$ s) for all groups in Experiment 1

\begin{tabular}{lcccccc}
\hline Group & \multirow{2}{*}{ WM } & & 0 aux & 1 verb & 2 prep & 3 det \\
\hline High-WM & $88(8)$ & SR_short & $531(141)$ & $785(314)$ & $479(84)$ & $353(56)$ \\
natives & & OR_short & $506(125)$ & $762(317)$ & $541(128)$ & $376(77)$ \\
& & SR_long & $565(232)$ & $814(296)$ & $430(54)$ & $340(75)$ \\
Low-WM & $74(4)$ & SR_short & $494(113)$ & $596(203)$ & $431(104)$ & $353(64)$ \\
natives & & OR_short & $500(138)$ & $673(360)$ & $576(206)$ & $381(86)$ \\
& & SR_long & $429(145)$ & $708(427)$ & $464(118)$ & $355(54)$ \\
& & OR_long & $532(195)$ & $775(466)$ & $505(135)$ & $366(65)$ \\
High-WM L2 & D 83(8) & SR_short & $890(259)$ & $1132(305)$ & $559(148)$ & $490(157)$ \\
learners & G 91(3) & OR_short & $913(397)$ & $1342(310)$ & $617(187)$ & $441(136)$ \\
& & SR_long & $846(328)$ & $1225(236)$ & $573(222)$ & $463(180)$ \\
Low-WM L2 & D 62 (6) & SR_short & $766(248)$ & $1355(551)$ & $532(67)$ & $445(61)$ \\
learners & G 74(4) & OR_short & $723(204)$ & $1247(590)$ & $509(99)$ & $430(61)$ \\
& & SR_long & $814(445)$ & $1209(609)$ & $547(113)$ & $454(83)$ \\
& & OR_long & $865(376)$ & $1412(743)$ & $513(101)$ & $447(97)$ \\
\hline
\end{tabular}

significant difference in the four groups' mean WM span scores, $F(3,42)=$ 43.85, $p<.001$. Post hoc comparisons using Tukey HSD found that all group comparisons were significantly different, apart from those of the two high-span groups.

To investigate potential differences between these groups in their momentby-moment processing of the experimental items, a separate ANOVA per segment was run on the data, each with the within-subjects factors Sentence type (object relative/subject relative) and Sentence length (long/short) and the between-subject factor Group, with four levels (high-WM native speakers/lowWM native speakers/high-WM L2s/low-WM L2s). There were no effects on Segment 0 apart from one of Group, $F_{1}(3,39)=7.55, p<.001$, partial $\eta^{2}=$ $.37 ; F_{2}(3,189)=116.70, p<.001$, partial $\eta^{2}=.65$, reflecting the fact that the groups differed from each other in overall reading speed. Here the L2 learners were slower than the native speakers overall, but, interestingly, both high-WM groups were slower than their low-WM counterparts.

In the segment following disambiguation (1), there was a main effect of Group, $F_{1}(3,39)=7.51, p=.001$, partial $\eta^{2}=.37 ; F_{2}(3,189)=132.77$, $p<.001$, partial $\eta^{2}=.68$, and Sentence type, $F_{1}(1,39)=8.15, p=.007$, 
partial $\eta^{2}=.17 ; F_{2}(1,63)=4.43, p=.039$, partial $\eta^{2}=.07$, and a three-way interaction among Sentence type, Length, and Group, which was significant by subjects, $F_{1}(3,39)=3.56, p=.023$, partial $\eta^{2}=.22 ; F_{2}(3,189)=1.20$, $p>$.3. This seemed to be caused by the high-WM L2 learners, who found the short OR sentences more difficult to process than the short SR, with the comparison significant in the subjects analysis, $t_{1}(9)=3.10, p=.013, \mathrm{n}^{2}=$ $.52 ; t_{2}(63)=.790, p>.4$. In contrast, there was no difference in mean RTs for any conditions for the other three groups. The high-WM span L2 learners' relatively higher RTs on the OR_short versus the OR_long items may be related to their comparably higher accuracy for the former versus the latter items seen in the verification task. If they had less trouble comprehending the OR_short items overall, then they are more likely to be able to integrate the arguments relatively early in the reading of the sentence. ${ }^{5}$

On the immediately following segment (2), there was a main effect of Group, $F_{1}(3,39)=1.42, p>.2 ; F_{2}(3,189)=10.15, p<.001$, partial $\eta^{2}=$ .14 , and Sentence type, $F_{1}(1,39)=8.34, p=.006$, partial $\eta^{2}=.18 ; F_{2}(1$, $63)=9.96, p=.002$, partial $\eta^{2}=.14$, and a significant interaction between the two, $F_{1}(3,39)=3.17, p=.035$, partial $\eta^{2}=.20 ; F_{2}(3,189)=4.40$, $p=.007$, partial $\eta^{2}=.07$. This reflects the fact that both groups of native speakers showed a processing advantage (of approximately $100 \mathrm{~ms}$ ) overall for the SR versus the OR sentences, whereas there was no such difference for the L2 learners. On this segment there was also a marginally significant three-way interaction among Sentence type, Length, and Group, $F_{1}(3,39)=2.53, p=$ .071 , partial $\eta^{2}=.16 ; F_{2}(3,189)=2.28, p=.080$, partial $\eta^{2}=.04$. This seemed to be driven by the fact that despite the overall processing advantage for the subject-resolved items found for both groups of native speakers, it was only the comparison between the long items that was statistically significant for high-WM group, $t_{1}(11)=5.21, p<.001, \mathrm{\eta}^{2}=.14 ; t_{2}(63)=2.52, p=.014$, $\eta^{2}=.09$, whereas the comparison was only statistically significant between the short items for the low-WM native speakers, $t_{1}(11)=3.24, p=.008, \mathrm{\eta}^{2}=.57$; $t_{2}(63)=2.37, p=.021, \mathrm{y}^{2}=.08$. None of the comparisons were significant in the L2 learner data.

Finally, on Segment 3, there was a main effect of Group, $F_{1}(3,39)=4.41$, $p=.009$, partial $\eta^{2}=.25 ; F_{2}(3,189)=35.15, p<.001$, partial $\eta^{2}=.36$, but no other effects.

In a parallel analysis, we investigated whether the groups' WM span score affected their ability to correctly respond to the verification statements that followed each experimental sentence and found that this was the case only for the native speakers (Sentence type $\times$ Sentence length $\times \mathrm{WM}: F(1,22)=5.27$, 
$p=.032$, partial $\left.\eta^{2}=.19\right)$. The lower $\mathrm{WM}$ native group responded with much less accuracy on the OR_long items (74\%) in contrast to the other three (SR_long: 89\%; SR_short: 92\%; OR_short: 80\%). Interestingly, this pattern looks very much like that of the L2 learners, who also achieved their lowest score in the OR_long items (73\%). For the higher WM group, this difference was not in evidence (OR_long: 89\%; SR_long: 92\%; SR_short: 97\%; OR_short: $86 \%$ ). Despite the effect of WM found in the native-speaker data, the results of an ANOVA with the between-subjects factor Group comprising three levels (High-WM native speakers/Low-WM native speakers/L2 learners) found no interaction with Group. This was because for all groups, the statements following subject relatives were responded to more accurately than those following object relatives, as were those following the short sentences in comparison to the long. This was reflected in both a significant main effect of both Sentence length, $F_{1}(1,45)=10.26, p=.019$, partial $\eta^{2}=.19 ; F_{2}(1,63)=$ $7.19, p=.009$, partial $\eta^{2}=.10$, and Sentence type, $F_{1}(1,45)=14.18, p<$ .001 , partial $\eta^{2}=.24 ; F_{2}(1,63)=41.31, p<.001$, partial $\eta^{2}=.40$.

To sum up the results of Experiment 1, the native speakers showed an overall subject preference in their online reading times, spending less time reading the $\mathrm{SR}$ versus the $\mathrm{OR}$ items. The learners showed an online processing advantage for subject relatives, but only those with high WM and then only for the short sentences. This latter pattern was also observed in the low-WM native speakers' processing, with statistically robust differences observed in the comparison between the short items. In contrast, there were no effects online at all in the data of the low-WM L2 learners. With regard to accuracy, numerically the L2 group patterned with the lower WM native speakers with much lower accuracy for the theoretically dispreferred OR_long items. Overall, however, the predicted subject preference appeared to hold for all groups, as shown by higher accuracy for these items versus the object-relative sentences.

\section{Discussion}

The goal of this experiment was to investigate whether German L2 learners of Dutch would behave similarly to Dutch native speakers when processing temporarily ambiguous subject- and object-relative clauses and to see whether WM span would affect the processing of the experimental items.

We found that the native speakers' online processing performance showed the subject-over-object preference for the temporarily ambiguous relative clause constructions that was predicted on the basis of earlier monolingual research (e.g., Mak, 2001; Vos, 1999). Working memory span had an effect on both the L2 and the native groups' overall processing of the experimental items. The L2 
group showed an online processing advantage for subject versus object relative clauses, but only those of higher WM span, and then only observed in the comparison between the short items, even though the processing preference for a subject versus an object reading for these kinds of constructions is known to be the same for native speakers of both German and Dutch. In this respect, the L2 learners patterned with the low-WM native speakers. Given that all the L2 learners performed like the native speakers offline, in that they were most accurate in their responses to the verification statements following the subject relatives in comparison to the object relative constructions, we can assume that they all had a preference for subject- versus object-relative clauses, as they would in their native language. The question then arises as to why an online processing advantage for subject relatives was not observed for all of the L2 learners.

An examination of the L2 learners' RTs showed that they were extremely high and rather variable, and it occurred to us that the task that they had to undertake may have been rather difficult. This may explain why only those highWM L2 learners showed the online processing advantage for subject relatives and why this was the case only for the short items. This may also be why the low-WM natives and the L2 learners as a whole achieved a very low score for the OR_long items, where performing the task may have proved too much of a burden. Additionally, recall that verification statements followed each item in the reading study, and this aspect of the task may have directed the readers to exactly those parts of the sentences that were crucial for obtaining the correct interpretation of the sentence: both NPs and the disambiguating verb; that is, it is possible that the readers may have realized early on in the experiment that the verification statements always targeted the agent and patient roles of the NPs and thus they may not have been reading the sentences in a natural way, for meaning. It is also possible that the large RTs and standard deviations might have masked any effects of the experimental manipulations. To see whether the observed effects were driven by these aspects of the experimental task, we ran a second experiment in which the readers were required to respond to verification statements only $25 \%$ of the time. The fact that there were 64 experimental items but only 16 fillers might also have gone some way in focusing the readers' attention on the experimental manipulation. Therefore, in the second experiment there was a 1:1 ratio between experimental items and fillers (64 of each).

In this way, we attempted to remove the focus from the experimental manipulations, and to ensure as far as possible that the sentences were read more for meaning, while keeping the two experiments as similar as possible. 
Table 4 Proficiency scores German L2 learners in Experiment 2

\begin{tabular}{llccccc}
\hline & & Reading & Writing & Listening & Speaking & Total mean \\
\hline L2 learners & Mean & 89.7 & 86.42 & 83.25 & 75.88 & 84.45 \\
& $S D$ & 4.27 & 7.56 & 11.23 & 5.76 & 4.34 \\
\hline
\end{tabular}

Note. Maximum score for each part is 100 . To pass the exam one needs at least a score of 60 .

\section{Experiment 2}

\section{Method}

\section{Participants}

The L2 group comprised 24 native speakers of German (1 male, 23 females; mean age $=20.2 ; S D=1.4)$. Sixteen of these attended the same language course as the L2 group in Experiment 1, given 1 year later at the Radboud University in Nijmegen. The other eight participants attended a highly similar language course at the University of Groningen. All participants passed the Dutch exam. ${ }^{6}$ The L2 learners were matched for proficiency with those of Experiment 1, $F(1,38)=2.47, p>0.1$; see Table 4 for the results. A new L1 control group of 24 native speakers of Dutch, all university students, was also tested (7 males, 17 females; mean age $=21.8 ; S D=3.3$ ). All participants had normal or corrected-to-normal vision and were paid a small fee for participation.

\section{Materials}

The materials in Experiment 2 were identical to those used in Experiment 1. Experiment 2 differed in that only $25 \%$ of the sentences was followed by a verification sentence, and in only $25 \%$ of these statements was the subject/object interpretation of the NPs in the experimental sentences probed. The remaining statements concerned other aspects of the sentences. Both groups were highly accurate in answering the verification statements (L2 group $=93 \%$; Dutch $=$ 91\%). There were also a greater number of fillers in Experiment 2 (64 rather than 16). Apart from these changes, the procedure in Experiment 2 was identical to that in Experiment 1.

\section{Results}

Applying the same exclusion criteria as in Experiment 1 led to the removal of $0.27 \%$ of the data for the L1 group and $0.13 \%$ for the L2 group. Table 5 shows the mean RTs for both groups collapsed across the four segments in the critical regions.

The analyses performed were the same as in Experiment 1. We first investigated whether the participants' WM span scores affected their processing of 
Table 5 Mean reading times collapsed across the four critical segments in Experiment 2

\begin{tabular}{llllll}
\hline & & SR_short & OR_short & SR_long & OR_long \\
\hline Native speakers & RT & $404(111)$ & $428(113)$ & $397(109)$ & $417(115)$ \\
L2 learners & RT & $565(122)$ & $564(114)$ & $555(115)$ & $559(121)$ \\
\hline
\end{tabular}

Table 6 Mean $\mathrm{WM}$ span $(\mathrm{D}=$ Dutch, $\mathrm{G}=$ German $)$ and reading times $(S D \mathrm{~s})$ for all groups in Experiment 2

\begin{tabular}{lclcccc}
\hline Group & WM & & 0 aux & 1 verb & 2 prep & 3 det \\
\hline High-WM & \multirow{2}{*}{$87(4)$} & SR_short & $464(289)$ & $525(325)$ & $465(303)$ & $349(132)$ \\
natives & & OR_short & $431(206)$ & $658(561)$ & $514(345)$ & $406(221)$ \\
& & SR_long & $410(199)$ & $592(426)$ & $462(241)$ & $361(168)$ \\
Low-WM & \multirow{2}{*}{$71(5)$} & OR_long & $456(295)$ & $637(458)$ & $501(319)$ & $374(196)$ \\
natives & & OR_short & $356(137)$ & $386(241)$ & $368(191)$ & $328(243)$ \\
& & SR_long & $324(113)$ & $341(189)$ & $353(169)$ & $312(122)$ \\
& & OR_long & $326(114)$ & $357(176)$ & $368(209)$ & $322(171)$ \\
L2 learners & D 73(11) & SR_short & $517(203)$ & $834(557)$ & $493(199)$ & $412(149)$ \\
& G 81(10) & OR_short & $521(220)$ & $815(481)$ & $495(202)$ & $419(158)$ \\
& & SR_long & $502(212)$ & $799(477)$ & $504(197)$ & $416(139)$ \\
& & OR_long & $489(199)$ & $817(504)$ & $504(212)$ & $425(160)$ \\
\hline
\end{tabular}

the experimental items overall and found that this was the case for the native speakers only (Type $\times \mathrm{WM}: F(1,22)=12.01, p=.002$, partial $\mathrm{\eta}^{2}=.35$; WM: $F(1,22)=8.69, p=.007$, partial $\left.\mathrm{n}^{2}=.28\right)$. The ANOVA run to investigate the groups' word-by-word online processing included the between-subjects factor Group with three levels: High-WM native speakers ( $n=13$, scoring above the group median of 81); Low-WM native speakers $(n=11)$; and the L2 learners, and as in Experiment 1, the within-subjects factor Sentence type (OR/SR) and Length (long/short). Table 6 shows the mean WM span score ${ }^{7}$ and the mean RTs per segment for all groups.

As can be seen from the mean RTs, the L2 learners read all of the segments more slowly than the native speakers, and the high-WM native speakers read the items more slowly than the low-WM native speakers, which was reflected in the significant main effect of Group on all segments (Segment 0: $F_{1}(2,45)=12.30, p<0.001$, partial $\eta^{2}=.35 ; F_{2}(2,126)=256.83, p<$ 0.001 , partial $\mathrm{\eta}^{2}=.55$; Segment 1: $F_{1}(2,45)=14.22, p<0.001$, partial $\mathrm{\eta}^{2}=.39 ; F_{2}(2,126)=270.61, p<0.001$, partial $\eta^{2}=.81$; Segment 2 : 
$F_{1}(2,45)=4.11, p=.023$, partial $\eta^{2}=.15 ; F_{2}(2,126)=120.41, p<0.001$, partial $\mathrm{\eta}^{2}=.87$; Segment $3: F_{1}(2,45)=4.77, p=.013$, partial $\eta^{2}=.18$; $F_{2}(2,126)=111.66, p<0.001$, partial $\left.\eta^{2}=.64\right)$. This pattern was similar to that seen in Experiment 1, in which those with a higher WM span spent longer reading the experimental items than those with a lower WM span. This slower reading may be the result of those with more WM capacity being able to keep both interpretations of the ambiguous sentences activated, as has been argued for on the basis of similar findings in other (monolingual) studies (MacDonald, Just, \& Carpenter, 1992; Pearlmutter \& MacDonald, 1995).

On Segment 0, where the disambiguating auxiliary was presented, there was also a significant main effect of Sentence length, $F_{1}(1,45)=7.19, p=.01$, partial $\eta^{2}=.14 ; F_{2}(1,63)=6.56, p=.013$, partial $\eta^{2}=.09$, and a three-way interaction among Sentence type, Length, and Group, $F_{1}(2,45)=3.76, p=$ .031 , partial $\mathrm{\eta}^{2}=.14 ; F_{2}(2,126)=3.65, p=.036$, partial $\eta^{2}=.06$. The L2 learners and both the native-speaker groups spent more time reading the short SR items in comparison to the long SR items, although this comparison was not significant for the L2 learners $(p \mathrm{~s}>.1)$, and only significant by items in the high-WM native speakers, $t_{1}(12)=-1.88, p=.084, t_{2}(63)=-2.50, p=$ $.015, \mathrm{n}^{2}=.09$, whereas it was robust for the low-WM native speakers, $t_{1}(10)=$ $-3.12, p=.011, \mathrm{\eta}^{2}=.49 ; t_{1}(63)=-2.12, p=.038, \mathrm{\eta}^{2}=.07$. The L2 group and the low-WM native speakers also showed a similar pattern in the comparison between the OR items, with the shorter sentences giving rise to the longer RTs, although it was only significant for the $\mathrm{L} 2$ learners in the subjects analysis (OR_long vs. OR_short: $t_{1}(23)=-2.07, p=.05, \mathrm{n}^{2}=.16 ; t_{1}(63)=$ $-1.602, p>.1)$. This pattern suggests that for all groups, work on argument integration began earlier in these short sentences (already at the point of disambiguation, the auxiliary verb), probably because in the short conditions, there is less semantic information that needs to be processed at this point in comparison to the long items, where there was also a padding phrase to be semantically integrated into the sentence. More interestingly, the high-WM native speakers processed the items at this position differently from both the low-WM native group and the L2 learners, showing a processing advantage for the $\mathrm{SR}$ versus the OR sentences in the long condition, although this comparison was not statistically robust, $t_{1}(12)=2.11, p=.057, \mathrm{y}^{2}=.27 ; t_{1}(63)=1.61$, $p>.1$.

On the segment immediately following disambiguation (1), where the lexical verb was presented, there was a significant main effect of Sentence type, $F_{1}(1,45)=8.76, p=.005$, partial $\mathrm{n}^{2}=.16 ; F_{2}(1,63)=6.34, p=.014$, partial $\mathrm{\eta}^{2}=.09$, and a significant interaction between Sentence type and Group, 
$F_{1}(2,45)=6.26, p=.004$, partial $\eta^{2}=.22 ; F_{2}(2,126)=3.51, p=.052$, partial $\mathrm{\eta}^{2}=.05$, as well as between Sentence length and Group, $F_{1}(2,45)=$ $3.63, p=.035$, partial $\eta^{2}=.14 ; F_{2}(2,126)=3.13, p=.048$, partial $\eta^{2}=.05$. There was no significant difference between the long and the short items overall for either the L2 learners ( $808 \mathrm{~ms}$ vs. 830) or the high-WM native speakers (621 ms vs. 594), whereas there was a significant difference for the low-WM native speakers, who showed the same pattern of comparatively higher RTs for short items as they did on the previous segment (long: 349 ms vs. short: 393 ms: $\left.t_{1}(10)=-2.94, p=.015 ; \mathrm{\eta}^{2}=.46 ; t_{2}(63)=-2.41, \mathrm{p}=.019, \mathrm{\eta}^{2}=.08\right)$. At this position however, the low-WM native group also spent longer reading the OR sentences overall than the SR ones $\left(378 \mathrm{~ms}\right.$ vs. $364 \mathrm{~ms}: t_{1}(10)=2.33$, $\left.p=.042, \mathrm{y}^{2}=.35 ; t_{2}(63)=1.11, p>.1\right)$ patterning with the high-WM native speakers in this respect (655 ms vs. $560 \mathrm{~ms}: t_{1}(12)=3.12, p=.009, \mathrm{\eta}^{2}=.34$; $\left.t_{2}(63)=2.56, p=.013, \eta^{2}=.09\right)$. In contrast to both native-speaker groups, the L2 learners did not show any advantage for either sentence type (OR: 819 ms vs. SR: $819 \mathrm{~ms}$ ).

On the two segments following disambiguation ( 2 and 3 ) there was a main effect of Sentence type, significant by subjects (Segment 2: $F_{1}(1,45)=8.14$, $p=.007$, partial $\eta^{2}=.15 ; F_{2}(1,63)=3.43, p=.069$, partial $\eta^{2}=.05 ;$ Segment 3: $F_{1}(1,45)=11.75, p=.001$, partial $\eta^{2}=.21 ; F_{2}(1,63)=3.54, p=.064$, partial $\left.\mathrm{\eta}^{2}=.05\right)$ and a significant interaction between Sentence type and Group, also by subjects (Segment 2: $F_{1}(2,45)=4.11, p=.023$, partial $\eta^{2}=.15 ; F_{2}(2$, $126)=2.22, p>0.1$; Segment $3: F_{1}(2,45)=3.24, p=.049$, partial $\eta^{2}=.13$; $\left.F_{2}(2,126)=1.06, p>0.3\right)$. There were no significant differences between the sentence types for either the L2 learners (Segment 2: 499 ms vs. 498; Segment 3: $421 \mathrm{~ms}$ vs. 412) or the low-WM native speakers (Segment 2: $373 \mathrm{~ms}$ vs. 361; Segment 3: $328 \mathrm{~ms}$ vs. 320). However, the high-WM native speakers continued to find the OR sentences significantly more difficult to process than the SR sentences on both Segment $2\left(390 \mathrm{~ms}\right.$ vs. $355 \mathrm{~ms}: t_{1}(12)=3.73, p=.003$, $\left.\mathrm{\eta}^{2}=.54 ; t_{2}(63)=2.03, p=.046, \mathrm{\eta}^{2}=.06\right)$ and Segment $3(421 \mathrm{~ms}$ vs. 412 : $\left.t_{1}(12)=3.45, p=.005, \mathrm{\eta}^{2}=.37 ; t_{2}(63)=2.20, \mathrm{p}=.031, \mathrm{\eta}^{2}=.07\right)$.

To sum up the results of Experiment 2, at the point of disambiguation both the native speakers and the L2 learners spent longer reading the short items versus the long items, and this effect continued on into the next segment for the low-WM native speakers, suggesting a more immediate start to the process of argument integration in the short items, irrespective of whether the items were subject- or object-resolved. The high-WM native speakers showed a processing advantage for subject versus object sentences overall from the disambiguation point (Segment 0) onward, whereas, statistically, the lower WM native speakers 
only showed this effect on Segment 1. Additionally, even though earlier research has shown that the longer a reader is committed to an erroneous analysis (i.e., as would be the case in the OR_long sentences), the more difficult recovery should be (e.g., Pickering \& Traxler, 1998), this effect in the native speakers' RTs was equally large for both the long and the short sentences. For the L2 learners there was no processing advantage or disadvantage for any sentence type on any of the critical segments.

\section{General Discussion}

In the two experiments, we investigated whether German L2 learners of Dutch would process subject-object ambiguities in relative clauses like native Dutch speakers and asked whether WM span would affect the participants' processing of these constructions. Given that this type of relative clause construction is highly comparable between Dutch and German and that monolingual speakers of both languages have the same subject-over-object preference, we provided an ideal situation for L1 transfer of processing preferences to take place, and so we might have expected the German L2 learners of Dutch to perform online like the Dutch native speakers. However, even though the L2 learners (like the native speakers) appeared to have a preference for subject versus object relatives as measured offline (they were more accurate in responding to the verifications statements following the subject relative clauses), this preference was not observed online for all L2 learners in both experiments. In contrast to the native Dutch speakers, who showed a processing advantage overall for the subject versus the object relative clauses in both Experiment 1 and Experiment 2, the online preference for subject-resolved sentences was only found for the high-WM L2 learners in the comparison between the short sentences, and then only in the first experiment. In the second experiment, where the participants were not required to perform the semantic verification task after each sentence, no such processing effects were observed at all for the L2 learners, and their processing was not affected by their WM capacity. In contrast, for the native speakers, WM affected their moment-by-moment processing in both experiments, although an overall subject-relative preference was observed. These results raise some questions, each of which is discussed below.

As stated earlier, in Experiment 2, the participants were not required to perform the verification task after every sentence, and so we can be more certain that the sentences were read more naturally than in Experiment 1. This did not qualitatively affect the native Dutch speakers' subject-first preference, as they had the same processing advantage for subject versus object relatives in both 
experiments, even though it is possible that while reading, they were additionally employing a strategy for responding to the verification statements-perhaps zooming in on the argument roles of the NPs in the ambiguous region. However, the high-WM native speakers showed an online preference for subject-relatives in the long condition, whereas this pattern was seen in the comparison between the short items for both the low-WM native speakers and the high-WM L2 learners. Additionally, both of these latter groups achieved a relatively poor score for the OR_long items in comparison to the other conditions, whereas the high-WM natives were much more accurate across the board. Taken together, these results suggest that processing the sentences in order to perform the task in Experiment 1 was more difficult for those of lower WM capacity and that L2 learners under certain conditions may look rather like some native speakersthat is, those of more restricted processing capacities (see, e.g., Indefrey, 2006, for a similar point).

The Dutch native speakers' processing of the experimental sentences was affected by WM in Experiment 1 and Experiment 2, whereas this was the case for the L2 learners in Experiment 1 only. Because it was only the number and type of verification statements that differed across the two experiments and because the two L2 learner groups were highly matched for proficiency and educational experience, it appears that it was the necessity to perform the task after every sentence that underlies the effect observed in Experiment 1 for the L2 learners. The comparison of the results of the two experiments may in fact speak to the issue of why studies of L2 real-time sentence comprehension have found mixed results with regard to whether L2 learners are nativelike in their online use of syntactic information. Those who have found L2 learners indistinguishable from native speakers have often required their participants to perform tasks that one could argue direct the readers' attention to the experimental manipulation. For example, in Juffs and Harrington's (1995) study, the participants performed a grammaticality judgment on each sentence after its presentation, and in Hopp's (2006) study, each item was followed by a truth value judgment. These tasks are both akin to our task in Experiment 1, in which the readers were required to make a semantic judgment after each and every item, which targeted the region of interest (i.e., the arguments of the verb); recall that it was only in our Experiment 1 that any of the L2 learners performed like native speakers. In contrast to this, studies that have found that L2 learners appear to underuse syntactic information online, for instance in their processing of syntactic dependencies, have required participants to read for meaning. Although the task in our Experiment 2 was the same as that in Experiment 1 (semantic verification), the fact that the participants only had to 
perform the task after 16 out of the 64 experimental sentences (and in only 4 of these was the experimental manipulation targeted; $6.25 \%$ ), we believe that we, too, attempted to avoid as much as possible the focusing of readers' attention on the experimental manipulations, and so Experiment 2 in the current study is more akin to these latter L2 processing studies (Felser \& Roberts, 2007; Marinis et al., 2005; Papadopoulou \& Clahsen, 2003). Although, of course, self-paced reading is not a highly natural reading task, we are more convinced that it is less likely in Experiment 2 than in Experiment 1 that participants are only focusing on the information necessary to perform the task successfully, and so more likely that they are reading for meaning.

If it is the case that the high-WM L2 learners' processing advantage for SR items found in Experiment 1 was driven by this aspect of the experimental task, the question now arises as to what is different between L1 and L2 processing in general, given the fact that the constructions tested were highly comparable in both languages and, thus, an ideal opportunity for transfer of L1 processing preferences was provided. One might argue that the experimental manipulation was not effective enough to produce the predicted subject preference online in our groups of L2 learners, but this seems unlikely for two reasons. First, the native speakers in both experiments (where the items were identical) showed the predicted RT advantage for the subject-relative clauses in comparison to the object-relative clauses and, second, the L2 learners were more accurate in responding to the verification statements following the SRs in Experiment 1, suggesting that they did indeed have a preference for a subject reading for these sentences and that the experimental manipulation was effective. One possibility is that the learners in this study differ from native speakers in that they had trouble computing subject-verb agreement online. This is possible given the results of Jiang (2004), who tested whether Chinese L2 learners of English were sensitive to number agreement violations online, using sentences like The bridge/s to the island were about ten miles away. The learners were able to select the correct verb for the appropriate subject in a written forcedchoice test, but they did not find ungrammatical agreement sentences more difficult to process online than grammatical ones, and the author concluded that the learners' morphological knowledge of English was not automatized. It therefore might be the case that for the learners in the current study, such knowledge is also not yet automatized. We did not specifically test the learners in the current study on their online ability to compute subject-verb agreement, but we might assume that they are able to do so because they achieved more than the required $60 \%$ on the proficiency test set to determine whether they were proficient enough to study at a Dutch university (mean $82 \%$ and $85 \%$ 
in Experiment 1 and Experiment 2, respectively). Perhaps a more compelling argument against this explanation is that others have found an effect of the L1 in this respect; that is, the lack of sensitivity found for Jiang's Chinese L2 learners may be caused by the fact that unlike English, Chinese does not have subject-verb agreement, nor are nouns morphologically marked for plural. Evidence that a learner's L1 might play a role in online subject-verb agreement processing comes from, for example, Lee (2002), who found that Chinese L2 learners processed subject-verb agreement violations differently from native English speakers, unlike the group of Spanish L2 learners also tested, who patterned together with the English group. The L1 of the L2 learners in the current study (German) patterns like Dutch in this respect.

Another explanation for the fact that the L2 learners as a whole did not perform in the same way as the native control Dutch group might be that they were not proficient enough in Dutch. If one looks at the length of residence and the proficiency levels of the (advanced) L2 learners in the Hopp (2006) study, for instance, it is clear that the German L2 learners who participated in the current study were less advanced and likely to be less experienced. We would argue, however, that the L2 learners were all proficient enough to undertake university classes in their L2, and so they cannot be classed as "beginning" learners. Additionally, the stimulus sentences used in the current study were also rather simpler than the scrambled sentences used in the Hopp study, and we were careful that all the vocabulary used came from a basic Dutch L2 learner vocabulary book. It is therefore likely that the L2 learners were proficient enough to understand the experimental items; it is particularly striking to compare the lowest accuracy score following the object-resolved sentences of our L2 learners (73\%) to those of Hopp (English advanced learners: 23\%). Nevertheless, it is certainly possible that a more highly proficient L2 group would show the online processing preference, given enough experience with the L2, and this would need to be tested with a more advanced German L2 learner group. ${ }^{8}$

An alternative possibility is that the difference between the L2 learners and the Dutch control group in Experiment 2 of the current study lies in their processing of the sentences before the disambiguating verb is encountered and before subject-verb agreement must be computed. On the basis of the findings of much research into monolingual sentence comprehension (e.g., Frazier, 1987; Frazier \& Flores d'Arcais, 1989; Gorrell, 2000; Kaan, 1997; Konieczny et al., 1997; Mecklinger et al., 1995; Schriefers et al., 1995; van Gompel, 1995), we assume the following for native speakers' processing of such subject-object ambiguities: While incrementally processing the sentences, on meeting the 
relative pronoun (the filler), readers are alerted to an upcoming relative clause (RC) and they build up an expectation of the preferred subject RC analysis. In the case of object RCs, higher RTs in the disambiguating region are observed because the number information on the auxiliary is incompatible with this preferred analysis, and revision takes place, as the (disfavored) object relative clause must be computed. Given that the L2 learners as a whole did not show any RT disadvantage for the object-resolved sentences and none at all showed this effect in Experiment 2, it may be that the L2 learners in the current study failed to expect a subject-relative clause like native Dutch speakers (and also like native German speakers in comparable studies). If so, then this may be why they were not troubled when they encountered the disambiguating verb forcing a (theoretically dispreferred) object-relative analysis; that is, before the auxiliary verb was read, they had not constructed a subject analysis that needed revising.

The above explanation may be plausible given that our results are rather similar to those L2 studies that have investigated the processing of RC attachment ambiguities like The dean liked the secretary of the professors who was/were reading a letter. This construction is temporarily ambiguous in that the $\mathrm{RC}$ can conceivably modify either NP1 (the secretary) or NP2 (the professors) up until number information on the auxiliary disambiguates the constructions and forces resolution to either NP. The preference for modifying either the first or the second NP in such RC attachment ambiguities has been found to differ crosslinguistically. Native English speakers have been found to read the disambiguating region faster when the ambiguity is resolved toward an NP2 modification the professors were reading a letter (e.g., Clifton, 1993; Roberts, 2003), whereas Greek and German speakers prefer NP1 as the host for the RC. To investigate potential transfer effects, in a self-paced reading study Felser et al. (2003) looked at the online and offline attachment preferences of Greek and German in such RC constructions. The L2 learners showed no preference for the RC to be attached either to the first or the second NP, unless the complex noun phrase contained a thematic preposition with (i.e., only when biasing lexical-semantic information was available, which is not available in the genitive of sentences). Given that subject-verb agreement was used to disambiguate the sentences and that an online preference was observed for sentences containing thematic prepositions, it is not the case that these learners were unable to compute subject-verb agreement online. Rather, the difference appears to lie in the type of information available to guide the parser in online processing: When only structural information was available, the L2 learners were not garden-pathed, suggesting that they had not built up an analysis to 
be violated. Very similar and even more striking results were found by $\mathrm{Pa}$ padopoulou and Clahsen (2003) with L2 learners of Greek (with disambiguation achieved via gender agreement), because their participants' processing performance differed from native Greek speakers even though native speakers of their L1s (Spanish, German, and Russian) all have the same NP1 preference as native Greek speakers. In our study, as in the genitive RC constructions in the above two studies, there is no semantically biasing information available before the disambiguating verb, and so only structurally based preferences can be observed, and it is here that L2 learners seem to differ from native speakers.

One difference between our results and those of the above RC attachment ambiguity studies should be noted. Our L2 learners differed from native speakers in their online processing, whereas offline, in Experiment 1, they showed the same subject-over-object preference as the native speakers (as revealed by their accuracy scores). In contrast, the learners in the above two RC ambiguity studies also differed from the native-speaker controls in their offline preferences, which suggests that under no circumstances did they have an RC attachment preference with a complex genitive antecedent. One potential reason for the difference in offline findings of our study compared to the two RC studies mentioned earlier is the structural difference between the two sentence types investigated. In the RC attachment ambiguity I spoke to the secretary of the professor who..., the $\mathrm{RC}$ is an adjunct (an optional element) and, as such, may well be subject to different parsing principles (see, e.g., Frazier \& Clifton, 1996). In our study, in contrast, although the syntactic roles of the NPs are similarly ambiguous before the auxiliary was encountered, both are obligatory arguments of the verb, and from earlier research, it seems clear that L2 learners have no problem integrating arguments with their subcategorizers. The results of these L2 processing studies taken together suggest that this argument integration may be more easily achievable online when L2 learners have access to lexical-semantic information to aid integration.

\section{Conclusion}

In the current study, we provided only syntactic information for the readers to make use of in their online processing decisions while we provided an ideal opportunity for L1 processing preferences to be transferred to the processing of the L2. When the demands of the task focused the participants' attention on the experimental manipulation, the subject-object ambiguity, we found that some L2 learners performed like some native speakers; that is, L2 learners of higher 
WM performed similarly to native speakers of lower WM capacity, showing an online preference for subject-resolved sentences. However, when asked to read more for meaning, the L2 learners showed no such online RT advantage, and no effects of WM capacity were observed. Overall, the results suggest that when reading for comprehension, online processing in the L2 may differ from that of native speakers in that they are less able to use syntactic information in making online processing decisions. It is striking that this may be the case even when the parsing preferences are assumed to be identical in their L1. Of course, given that L2 online processing of lexical-semantic and plausibility information may be rather nativelike and that it may be subject to transfer effects, it remains to be seen whether an online processing preference for subject-first sentences could be observed in German L2 learners of Dutch by biasing toward one or other of the ambiguous NPs via semantic and/or plausibility information. The results of the current study suggest that in the absence of such information, L2 learners' processing decisions may be suspended in comparison to those of native speakers.

Revised version accepted 20 February 2008

\section{Notes}

1 See also Birner \& Ward, 1998, Givón, 1984, Kaiser \& Trueswell, 2004, Lambrecht, 1994, and Prince, 1998, for discussion on the discourse-based reasons for scrambling constructions, and see also the work done within the Referential Constraint Theory (e.g., Altmann \& Steedman, 1988; Crain \& Steedman, 1985) on why presenting scrambled sentences in isolation may cause processing difficulty not only because of structural complexity, but also because of the violation of discourse constraints.

2 In Dutch, the auxiliary can either precede or follow the participle, while in German it always follows the participle. We chose to use the auxiliary-participle order for the sentences in this experiment because with this order, the sentences are disambiguated before the participle is encountered. Therefore, disambiguation is primarily guided by syntactic information (number agreement) in all cases. If, despite the tests for plausibility, there were still preferred interpretations, participants would not be semantically biased before the point of syntactic disambiguation.

3 It was not possible to classify 5 participants according to this criterion; 2 achieved a high score on the German WM span test, but a low score on the Dutch, and 3 showed the opposite pattern. Therefore, to keep the data as clean as possible, we did not include these 5 participants in the WM analysis. 
4 An analysis comparing the native speakers WM span scores with the L2 learners' scores in the German WM span test provided very similar results scores $(F(3,42)$ $=43.95 ; p<0.001)$, but in this analysis both the high-span groups and the low-span groups did not differ significantly from one another.

5 We thank an anonymous reviewer for suggesting this.

6 The same Dutch exam was used at both universities. The only difference was that in Groningen the speaking section was not administered. The L2 speaking skills of these 8 participants was judged by the teachers to be sufficiently fluent. The participants from Nijmegen were tested 1 to 7 weeks after the exam, the Groningen participants 8 weeks after the exam.

7 As in Experiment 1, we ran a one-way between-groups ANOVA on the mean WM span scores. There was a statistically significant difference in the four groups' mean scores for both the Dutch WM span scores $(F(2,45)=14.52 ; p<0.001)$, and the comparison between the native speakers' scores and the L2 learners' German WM span scores $(F(2,45)=12.61 ; p<0.001)$. Post-hoc comparisons using Tukey HSD found that all group comparisons were significantly different in this latter analysis. In the post-hoc comparison between the groups Dutch WM span scores, the low-WM span native group did not significantly differ from the L2 learners (low-WM span native speakers: 71.3, $S D=5.4$; L2 learners: 72.9, $S D=11.1$ ), whereas all the other group comparisons were significant.

8 We thank an anonymous reviewer for suggesting this.

\section{References}

Altarriba, J., Kroll, J., Sholl, A., \& Rayner, K. (1996). The influence of lexical and conceptual constraints on reading mixed-language sentences: Evidence from eye fixations and naming times. Memory \& Cognition, 24, 477-492.

Altmann, G. T. M., \& Steedman, M. (1988). Interaction with context during human sentence processing. Cognition, 30, 191-238.

Bader, M., \& Meng, M. (1999). Subject-object ambiguities in German embedded clauses: An across-the-board comparison. Journal of Psycholinguistic Research, 28(2), 121-143.

Birner, B., \& Ward, G. (1998). Information status and noncanonical word order in English. Amsterdam: Benjamins.

Bornkessel, I., \& Schlesewsky, M. (2006). The role of contrast in the local licensing of scrambling in German: Evidence from on-line comprehension. Journal of Germanic Linguistics, 18(1), 1-43.

Clahsen, H., \& Felser, C. (2006a). Grammatical processing in language learners. Applied Psycholinguistics, 27(1), 3-42.

Clahsen, H., \& Felser, C. (2006b). How native-like is non-native language processing? Trends in Cognitive Science, 10(12), 564-570.

Clifton, C. (1993). Thematic roles in sentence parsing. Canadian Journal of Psychology, 47, 224-246. 
Clifton, C. J., \& Frazier, L. (1989). Comprehending sentences with long-distance dependencies. In G. N. Carlson \& M. K. Tanenhaus (Eds.), Linguistic structure in language processing (pp. 273-318). Dordrecht: Kluwer.

Crain, S., \& Steedman, M. (1985). On not being led up the garden path: The use of context in the psychological syntax processor. In D. R. Dowty, L. Karttunen, \& A. M. Zwicky (Eds.), Natural language parsing (pp. 320-358). Cambridge: Cambridge University Press.

Daneman, M., \& Carpenter, P. A. (1980). Individual differences in working memory and reading. Journal of Verbal Learning and Verbal Behavior, 19(4), 450-466.

de Kleijn, P., \& Nieuwborg, E. (2001). Basiswoordenboek Nederlands. Leuven: Wolters.

De Vincenzi, M. (1991). Syntactic parsing strategies in Italian. Dordrecht: Kluwer.

Felser, C., \& Roberts, L. (2004, September). Plausibility and recovery from garden-paths in L2 sentence processing. Poster presented at Architectures and Mechanisms for Language Processing (AMLaP), Aix-en-Provence, France.

Felser, C., \& Roberts, L. (2007). Processing wh-dependencies in English as a second language: A cross-modal priming study. Second Language Research, 23, 1-28.

Felser, C., Roberts, L., Gross, R., \& Marinis, T. (2003). The processing of ambiguous sentences by first and second language learners of English. Applied Psycholinguistics, 24, 453-489.

Frazier, L. (1987). Syntactic processing: Evidence from Dutch. Natural Language and Linguistic Theory, 5, 519-559.

Frazier, L., \& Clifton, C. (1996). Construal. Cambridge, MA: MIT Press.

Frazier, L., \& Flores d'Arcais, G. (1989). Filler driven parsing: A study of gap filling in Dutch. Journal of Memory and Language, 28, 331-344.

Frenck-Mestre, C., \& Pynte, J. (1997). Syntactic ambiguity resolution while reading in second and native languages. Quarterly Journal of Experimental Psychology, 50A, 119-148.

Friederici, A. D., Steinhauer, K., Mecklinger, A., \& Meyer, M. (1998). Working memory constraints on syntactic ambiguity resolution as revealed by electrical brain responses. Biological Psychology, 47(3), 193-221.

Givón, T. (1984). Syntax: A functional-typological introduction. Amsterdam: Benjamins.

Gorrell, P. (1995). Syntax and parsing. Cambridge: Cambridge University Press.

Gorrell, P. (2000). The subject-before-object preference in German clauses. In B. Hemforth \& L. Konieczny (Eds.), German sentence processing (pp. 25-64). Dordrecht: Kluwer.

Harrington, M., \& Sawyer, M. (1992). L2 working memory capacity and L2 reading skill. Studies in Second Language Acquisition, 14, 25-38.

Hopp, H. (2006). Syntactic features and reanalysis in near-native processing. Second Language Research, 22(3), 369-397. 
Indefrey, P. (2006). It is time to work toward explicit processing models for native and second language speakers. Applied Psycholinguistics, 27(1), 66-69.

Jiang, N. (2004). Morphological insensitivity in second language processing. Applied Psycholinguistics, 25(4), 603-634.

Juffs, A. (2004). Representation, processing and working memory in a second language. Transactions of the Philological Society, 102(2), 199-225.

Juffs, A. (2005). The influence of first language on the processing of $w h$-movement in English as a second language. Second Language Research, 21, 121-151.

Juffs, A., \& Harrington, M. (1995). Parsing effects in second language sentence processing: Subject and object asymmetries in wh-extraction. Studies in Second Language Acquisition, 17, 483-516.

Juffs, A., \& Harrington, M. (1996). Garden path sentences and error data in second language sentence positioning. Language Learning, 46(2), 283-232.

Just, M. A., \& Carpenter, P. A. (1992). A capacity theory of comprehension: Individual differences in working memory. Psychological Review, 99(1), 122-149.

Just, M. A., Carpenter, P. A., \& Woolley, J. D. (1982) Paradigms and processes in reading comprehension. Journal of Experimental Psychology: General, 111, $228-238$.

Kaan, E. (1997). Processing subject-object ambiguities in Dutch. Groningen Dissertations in Linguistics 20.

Kaiser, E., \& Trueswell, J. C. (2004). The role of discourse context in the processing of a flexible word-order language. Cognition, 94(2), 113-147.

King, J., \& Just, M. A. (1991). Individual differences in syntactic processing: The role of working memory. Journal of Memory and Language, 30(5), 580602.

Konieczny, L., Hemforth, B., Scheepers, C., \& Straube, G. (1997). The role of lexical heads in parsing: Evidence from German. Language and Cognitive Processes, 12, 307-348.

Lambrecht, K. (1994). Information structure and sentence form: Topic, focus and the mental representations of discourse referents. Cambridge: Cambridge University Press.

Lee, M. W. E. (2002, March). Implementing subject-verb number agreement in a non-native language. Poster presented at the 15th CUNY Conference on Human Sentence Processing, New York.

MacDonald, M., Just, M. A., \& Carpenter, P. A. (1992). Working memory constraints on the processing of syntactic ambiguity. Cognitive Psychology, 24(1), 56-98.

Mak, W. (2001). Processing relative clauses, effects of pragmatic, semantic and syntactic variables. Unpublished doctoral dissertation, Katholieke Universiteit Nijmegen, The Netherlands.

Marinis, T., Roberts, L., Felser, C., \& Clahsen, H. (2005). Gaps in second language sentence processing. Studies in Second Language Acquisition, 27, 53-78. 
Mecklinger, A., Schriefers, H., Steinhauer, K., \& Friederici, A. (1995). Processing relative clauses varying on syntactic and semantic dimensions: An analysis with event-related potentials. Memory \& Cognition, 23, 477-494.

Papadopoulou, D., \& Clahsen, H. (2003). Parsing strategies in L1 and L2 sentence processing: A study of relative clause attachment in Greek. Studies in Second Language Acquisition, 24, 501-528.

Pearlmutter, N. J., \& MacDonald, M. C. (1995). Individual differences and probabilistic constraints in syntactic ambiguity resolution. Journal of Memory and Language, 34, 521-542.

Pickering, M. J., \& Traxler, M. J. (1998). Plausibility and recovery from garden paths: An eye-tracking study. Journal of Experimental Psychology: Learning, Memory and Cognition, 24(4), 940-961.

Prince, E. F. (1998). On the limits of syntax, with reference to Topicalization and Left-Dislocation. In P. Culicover \& L. McNally (Eds.), Syntax and semantics: The limits of syntax 29 (pp. 281-302). New York: Academic Press.

Roberts, L. (2003). Syntactic processing in L2 learners of English. Unpublished doctoral thesis, University of Essex, UK.

Robinson, P. (2002). Effects of individual differences in intelligence, aptitude and working memory on incidental SLA. In P. Robinson (Ed.), Individual differences and instructed language learning. Philadelphia: Benjamins.

Schriefers, H., Friederici, A., \& Kuhn, A. (1995). The processing of locally ambiguous relative clauses in German. Journal of Memory and Language, 34, 499-520.

Van den Noort, M. W. M. L., Bosch, M. P. C., \& Hugdahl, K. (2006). Foreign language proficiency and working memory capacity. European Psychologist, 11(4), 289-296.

van Gompel, R. (1995). The processing of subject and object relative clauses in Dutch. Unpublished master's thesis, University of Nijmegen, The Netherlands.

Vos, S. H. (1999). Verbal working memory and sentence processing: An electrophysiological investigation. Unpublished doctoral dissertation, Katholieke Universiteit Nijmegen, The Netherlands.

Williams, J. (2006). Incremental interpretation in second language sentence processing. Bilingualism: Language and Cognition, 9(1), 71-88.

Williams, J., Möbius, P., \& Kim, C. (2001). Native and non-native processing of English wh-questions: Parsing strategies and plausibility constraints. Applied Psycholinguistics, 22, 509-540.

\section{Appendix}

\section{List of Experimental Sentences in Experiment 1 and Experiment 2}

1. Daar zit de werkgever die de werknemers (in een tijd van grote werkloosheid) heeft/hebben gevonden via een korte advertentie.

There is the employer who the employees has/have found through a short ad (in a period with a large amount of unemployment). 
2. Daar is de collega die de verpleegsters (aan het einde van de middag) heeft/hebben afgelost na een drukke dag.

There is the colleague who the nurses has/have relieved after a busy day (in the late afternoon).

3. Daar loopt de docent die de cursisten (vorige week tijdens de laatste les) heeft/hebben verrast met een lekkere taart.

There walks the teacher who the students has/have surprised with a nice cake (last week during the final lesson).

4. Dit is de broer die de zussen (de hele middag in de keuken) heeft/hebben meegeholpen om het eten te bereiden.

This is the brother who the sisters has/have helped to prepare the food (all afternoon in the kitchen).

5. Daar staat de kok die de obers (in de keuken van het restaurant) heeft/hebben verbaasd door het dessert te laten vallen.

There is the cook who the waiters has/have surprised by dropping the dessert (in the kitchen of the restaurant).

6. Daar fietst de moeder die de dochters (na een bezoek aan het theater) heeft/hebben gemotiveerd om een cursus toneel te volgen.

There cycles the mother who the daughters has/have motivated to attend a drama course (after a visit to the theater)

7. Daar staat de barman die de vriendinnen (bij het bestellen aan de bar) heeft/hebben verstaan in de drukke kroeg.

There is the barman who the friends has/have understood in the busy pub (while ordering at the bar).

8. Hier is de opa die de kinderen ('s avonds laat voor het slapen gaan) heeft/hebben gekust om een goede nacht te wensen.

Here is the grandfather who the children has/have kissed to wish a good night (late at night before going to bed).

9. Daar loopt de serveerster die de dames (tijdens het diner in het restaurant) heeft/hebben geïrriteerd met het onbeleefde gedrag.

There walks the waitress who the ladies has/have irritated with impolite behavior (during dinner at the restaurant).

10. Daar komt de gitarist die de zangers (na afloop van de goede repetitie) heeft/hebben meegenomen naar de leuke jazzclub.

There comes the guitarist who the singers has/have taken to an amusing jazz club (after the good rehearsal).

11. Dat is de huisarts die de assistentes (aan het begin van de lange werkdag) heeft/hebben gewaarschuwd dat het druk zou worden. 
That is the family doctor who the assistants has/have warned that it would be busy (at the beginning of a long working day).

12. Daar gaat de piloot die de stewards (vlak voor het vertrek naar Brussel) heeft/hebben herkend op het grote vliegveld.

There goes the pilot who the stewards has/have recognized at the large airport (just before the departure to Brussels).

13. Daar is de buitenlander die de buren (tijdens een feestje in de straat) heeft/hebben uitgenodigd om een keer te komen eten.

There is the foreigner who the neighbours has/have invited to have dinner sometime (during the party in the street).

14. Daar zit de vader die de zoons (drie jaar geleden in de oorlog) heeft/hebben verloren bij het hevige bombardement.

There is the father who the sons has/have lost during the heavy bombardment (three years ago during the war).

15. Daar gaat de trainer die de sporters (na de wedstrijd in het sportpark) heeft/hebben getrakteerd op een koud biertje.

There goes the trainer who the sportsmen has/have treated to a cold beer (after the match in the sports park).

16. Daar loopt de boerin die de buurvrouwen ('s middags rond een uur of vier) heeft/hebben gebeld om een kopje thee te gaan drinken.

There walks the woman farmer who the neighbors has/have phoned to have a cup of tea (around 4 o'clock in the afternoon).

17. Daar staat de Italiaan die de Duitsers (op het plein voor het station) heeft/hebben begrepen na een lang gesprek.

There is the Italian who the Germans has/have understood after a long conversation (at the square in front of the station).

18. Dit is de chef die de bedrijfsleiders (in het grote kantoor in Amsterdam) heeft/hebben gezocht om een vraag te stellen.

This is the boss who the managers has/have looked for to ask questions (at the large office in Amsterdam).

19. Hier is de huismeester die de bewoners (na de inbraak in het flatgebouw) heeft/hebben overtuigd om een nieuw slot te bestellen.

Here is the caretaker who the occupants has/have convinced to order a new lock (after the burglary in the flat).

20. Daar loopt de zwerver die de jongeren ('s avonds laat in de donkere straat) heeft/hebben bekeken met een vreemde blik.

There goes the homeless person who the youngsters has/have looked at with a strange look (late at night in a dark street). 
21. Dat is de postbode die de bakkers (vanmorgen om een uur of acht) heeft/hebben gegroet door een hand op te steken.

That is the mailman who the bakers has/have greeted by putting up a hand (this morning around 8 o'clock).

22. Dat is de kapper die de klanten (aan het einde van de middag) heeft/hebben opgebeld om een nieuwe afspraak te maken.

That is the hairdresser who the customers has/have phoned to reschedule the appointments (in the late afternoon).

23. Daar komt de buurman die de kennissen (op de stoep bij de voordeur) heeft/hebben gefeliciteerd aan het begin van het feest.

Here comes the neighbor who the acquaintances has/have congratulated at the beginning of the party (on the pavement near the front door).

24. Daar zit de nicht die de neefjes (op een warme dag in augustus) heeft/hebben opgezocht in de nieuwe woonplaats.

There is the cousin who the cousins has/have visited at the new address (on a warm day in August).

25. Dit is de Spanjaard die de Nederlanders (vorige week om één uur 's nachts) heeft/hebben opgehaald van het station in de stad.

This is the Spaniard who the Dutch people has/have picked up from the station in the town (last week at one o'clock in the morning).

26. Daar gaat de juffrouw die de kinderen (op het plein voor de school) heeft/hebben uitgezwaaid op de laatste schooldag.

There goes the teacher who the children has/have sent off on the last day of school (at the square in front of the school).

27. Daar fietst de studiegenoot die de jongens (bij een borrel in het studentencafé) heeft/hebben geadviseerd om de goede CD te kopen.

There cycles the college friend who the boys has/have advised to buy the good CD (during a drink at the student pub).

28. Dit is de peuter die de ouders ('s ochtends vroeg om kwart voor zeven) heeft/hebben gewekt na een korte nacht.

This is the toddler who the parents has/have woken up after a short night (early in the morning at a quarter to seven).

29. Daar zit de hoogleraar die de wetenschappers (op een grote conferentie in Cambridge) heeft/hebben geprezen om het goede onderzoek.

There is the professor who the scientist has/have praised for the fine research (at a large conference in Cambridge).

30. Daar staat de jogger die de mannen (bij de ingang van het sportpark) heeft/hebben uitgedaagd om een wedstrijd te rennen. 
There is the runner who the men has/have challenged to run a contest (at the entrance of the sports park).

31. Daar komt de kleuterleidster die de kleuters (de vorige zomer bijna elke dag) heeft/hebben gemist in de lange vakantie.

Here comes the nursery school teacher who the pre-schoolers has/have missed during the long holiday (last summer almost every day).

32. Daar is de hond die de inbrekers (bij de voordeur van het huis) heeft/hebben gehoord in de stille nacht.

There is the dog who the burglars has/have heard in the silent night (near the front door of the house).

33. Daar gaat de fietser die de wandelaars (op een paadje in het bos) heeft/hebben gehinderd bij het passeren.

There goes the cyclist who the walkers has/have hindered while passing (on a path in the forest).

34. Hier is de leraar die de leerlingen (voor het begin van de les) heeft/hebben opgewacht in de lange gang.

Here is the teacher who the students has/have waited for in the long hallway (before the beginning of the lesson).

35. Daar staat de presentator die de kandidaten (bij de spannende quiz op televisie) heeft/hebben omhelsd toen de prijs werd gewonnen.

There is the host who the candidates has/have hugged when the prize was won (in the thrilling quiz on TV).

36. Daar staat de Amerikaan die de vrienden (tijdens de vakantie in de bergen) heeft/hebben gefilmd met de luxe camera.

There is the American who the friends has/have filmed with the luxury camera (during the vacation in the mountains).

37. Daar fietst de buurjongen die de meisjes (op het pleintje achter de huizen) heeft/hebben geduwd bij een ruzie over de knikkers.

There cycles the neighbor boy who the girls has/have pushed at a fight over the marbles (at the little square behind the houses).

38. Daar zit de gastvrouw die de gasten (tijdens het feestje in de tuin) heeft/hebben verveeld met de saaie verhalen.

There is the hostess who the guests has/have bored with the tedious stories (during the party in the garden).

39. Daar komt de sponsor die de kunstenaars (voor de opening van de tentoonstelling) heeft/hebben genoemd in het interview voor de krant.

Here comes the sponsor who the artist has/have named in the interview for the newspaper (before the opening of the exhibition). 
40. Dit is de mevrouw die de bejaarden (in een lange brief uit Spanje) heeft/hebben geschreven over de leuke vakantie.

This is the lady who the elderly people has/have written about the pleasant vacation (in a long letter from Spain).

41. Dat is de drugsdealer die de criminelen (na een ruzie over de betaling) heeft/hebben vermoord in het donkere pakhuis.

That is the drug dealer who the criminals has/have murdered at the dark warehouse (after a fight about the payment).

42. Daar is de president die de ministers (tijdens een overleg in een restaurant) heeft/hebben gevraagd om het voorstel te steunen.

There is the president who the ministers has/have asked to support the proposition (during a meeting in a restaurant).

43. Daar is de machinist die de conducteurs (na het ongeluk met de trein) heeft/hebben bevrijd uit het brandende treinstel.

There is the train driver who the conductors has/have freed from the burning train (after the train accident).

44. Daar gaat de toerist die de reizigers (bij het hostel midden in Bangkok) heeft/hebben geholpen met het dragen van de bagage.

There goes the tourist who the travelers has/have helped with the carrying of the luggage (near the hostel in the middle of Bangkok).

45. Daar zit de receptioniste die de telefonistes (aan het einde van de middag) heeft/hebben vervangen voor een paar uur.

There is the receptionist who the telephonists has/have replaced for a couple of hours (at the end of the afternoon).

46. Dat is de generaal die de militairen (in de colonne bij de rivier) heeft/hebben gealarmeerd toen de vijand naderde.

That is the general who the soldiers has/have alarmed when the enemy approached (in the party near the river).

47. Daar loopt de Fransman die de Engelsen (de hele dag met veel plezier) heeft/hebben begeleid bij het bezoek aan de stad.

There goes the Frenchman who the Englishmen has/have guided at the visit to the town (all day with pleasure).

48. Daar loopt de vriendin die de zusjes (in de winter vanuit de tuin) heeft/hebben geroepen om een grote sneeuwman te maken.

There goes the girl friend who the sisters has/have called to make a large snowman (in the winter from the garden).

49. Daar staat de professor die de studenten (tijdens de pauze rond half twee) heeft/hebben gezien in de drukke kantine. 
There is the professor who the students has/have seen in the busy cafeteria (during the break around half past one).

50. Dat is de baron die de butlers (in de kelder van het landhuis) heeft/hebben vermoord met een oud pistool.

There is the baron who the butlers has/have murdered with an old gun (in the basement of the manor).

51. Daar is de makelaar die de kopers (om kwart over drie in Nijmegen) heeft/hebben verwacht om de villa te bekijken.

There is the real estate agent who the buyers has/have expected to have a look at the manor (at a quarter past three in Nijmegen).

52. Daar komt de dirigent die de muzikanten (op het podium van de concertzaal) heeft/hebben aangekeken bij de prachtige uitvoering.

Here comes the conductor who the musicians has/have looked at at the wonderful performance (at the stage of the concert hall).

53. Daar staat de burgemeester die de wethouders (dit jaar in de maand september) heeft/hebben gesteund bij de crisis in de gemeente.

There is the mayor who the aldermen has/have supported at the crisis in the municipal (this year in the month of September).

54. Daar loopt de arts die de specialisten (bij het afscheid in het ziekenhuis) heeft/hebben bedankt voor de fijne samenwerking.

There goes the doctor who the specialists has/have thanked for the fine cooperation (at the farewell in the hospital).

55. Daar zit de koningin die de prinsessen (bij het bal in het paleis) heeft/hebben bewonderd om de dure oorbellen.

There is the queen who the princesses has/have admired for the expensive earrings (at the ball at the palace).

56. Daar gaat de Griek die de vrouwen (deze zomer op het zonnige Kreta) heeft/hebben bekeken op het drukke strand.

There goes the Greek who the women has/have looked at on the busy beach (this summer on sunny Crete).

57. Daar fietst de student die de huisgenoten (aan het einde van het feest) heeft/hebben aangetroffen op de trap van de flat.

There cycles the student who the roommates has/have found on the stairs of the apartment (at the end of the party).

58. Daar is de tante die de ooms (op het kerkhof buiten het dorp) heeft/hebben gecondoleerd na de treurige begrafenis.

There is the aunt who the uncles has/have consoled after the sad funeral (at the cemetery outside the village). 
59. Daar komt de boer die de knechten (in het weiland naast de boerderij) heeft/hebben gered van de wilde stier.

Here comes the farmer who the farm hands has/have saved from the wild bull (in the grass-land next to the farm).

60. Daar loopt de portier die de bezoekers (in het museum voor moderne kunst) heeft/hebben aangesproken over het gebruik van de garderobe.

There goes the porter who the visitors has/have addressed about the use of the wardrobe (at the museum of modern art).

61. Dit is de detective die de politieagenten (tijdens het overleg op het politiebureau) heeft/hebben geïnformeerd over de vreemde moord.

This is the detective who the policemen has/have informed about the strange murder (during the meeting at the police station).

62. Daar rijdt de cowboy die de indianen (op de prairie buiten de stad) heeft/hebben beroofd van een mooi paard.

There rides the cowboy who the Indians has/have robbed of a beautiful horse (at the prairie outside town).

63. Dat is de soldaat die de vijanden (na een gevecht in de nacht) heeft/hebben gedood in de verlaten stad.

That is the soldier who the enemies has/have killed in the deserted town (after a fight in the night).

64. Daar zit de bruid die de zwagers (na de bruiloft in het stadhuis) heeft/hebben gezoend op de drukke receptie.

There is the bride who the brothers-in-law has/have kissed at the busy reception (after the wedding in the city hall). 